4. Rubio C. Navarro-Sánchez L., GarcíaPascual C.M., et al. (2020). "Multicenter prospective study of concordance between embryonic cell-free DNA and trophectoderm biopsies from 1301 human blastocysts." Am J Obstet Gynecol.

5. Liu W., Liu J., Du H., et al. (2017). "Noninvasive pre-implantation aneuploidy screening and diagnosis of beta thalassemia IVSII654 mutation using spent embryo culture medium." Ann Med, 49(4), 319-328.
6. Shamonki M.I., Jin H., Haimowitz Z., et al. (2016). "Proof of concept: preimplantation genetic screening without embryo biopsy through analysis of cell-free DNA in spent embryo culture media." Fertility and Sterility, 106(6), 1312-1318.

7. Vera-Rodriguez M., Diez-Juan A., JimenezAlmazan j., et al. (2018). "Origin and composition of cell-free DNA in spent medium from human embryo culture during preimplantation development." Hum Reprod, 33(4), 745-756.

\title{
KHẢO SÁT NỒNG Độ ACID URIC HUYẾT TƯƠNG Ở BÊNH NHÂN ĐÁI THÁO ĐƯờNG TÍP 2 CÓ BỆNH THẬN MẠN
}

Đào Bùi Quý Quyền ${ }^{1}$, Bùi Hữu Hoàng ${ }^{2}$, Lê Việt Thắng ${ }^{3}$

\section{TÓM TẮT}

Mục tiêu: Xác định nồng độ acid uric huyết tương ở bênh nhân đái tháo đường típ 2 có bênh thân man. Đối tượng và phương pháp: Nghiên cứu cắt ngang trên 156 đối tương bao gồm 98 bênh nhân ĐTĐ típ 2 có BTMT và 58 bệnh nhân không có BTMT. Tất cả các bênh nhân được định lượng nồng đôacid uric huyết tươngtheo phương pháp enzyme. Kết quả: Nồng độ hs-CRP huyết tương trung bình ở nhóm ĐTĐ có BTMT

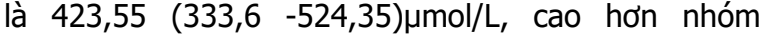

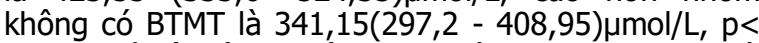
0,001 . Tỷ lệ bệnh nhân ĐTĐ có BTMT tăng AU là $60,2 \%$ cao hớn nhóm không có BTMT là $29,3 \%$, $p<$ 0,001 . Nhóm bệnh nhân ĐTĐ có BTMT tuổi từ 60 trở lên; bệnh thận mạn giai đoạn 3-5; có biến chứng khác ngoài thân có nồng đô $A U$ cao hơn nhóm không có đặc điểm trên, $p<0,05$. Kết luận: Tăng $A U$ là thường gặp ở bênh nhân ĐTĐ típ 2 có bênh thân mạn.

Tư khóa: Đái tháo đường típ 2, bệnh thận mạn tính, acid uric

\section{SUMMARY}

SURVEY ON CONCENTRATION OF PLASMA ACID URIC IN TYPE 2 DIABETIC MELLITUS PATIENTS WITH CHRONIC NEPHROPATHY

Objectives:To determine of plasma acid uric (AU)levels in type 2 diabetic mellitus (DM) with chronic nephropathy (CN). Subjects and methods: Cross-sectional study on 156 subjects including 98 patients diagnosed type $2 \mathrm{DM}$ with $\mathrm{CN}$ and 58 patients without CN. Plasma AU levels were quantified by enzyme in all the patients. Results: The median plasma $\mathrm{AU}$ concentration in the $\mathrm{DM}$ group with $\mathrm{CN}$ was 423.55 (333.6-524.35) $\mu \mathrm{mol} / \mathrm{L}$, higher than the

\footnotetext{
${ }^{1}$ Bệnh viện Chơ rẫy,

²Bênh viện Nhân dân 115

${ }^{3}$ Họ viến Quân y

Chịu trách nhiệm chính: Lê Việt Thắng

Email: lethangviet@yahoo.com.uk

Ngày nhận bài: 12/4/2021

Ngày phản biên khoa hoc: 10/5/2021

Ngày duyệt bài: 23/5/2021
}

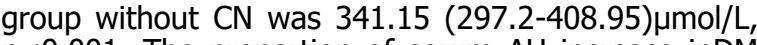
$\mathrm{p}<0.001$. The proportion of serum AU increase inDM patients with $\mathrm{CN}$ was $60.2 \%$ higher than that of the DM group without CN of $29.3 \%, p<0.001$. The AU concentration in group of DM patients with $\mathrm{CN}$ and $\geq$ 60 years old; $\mathrm{CN}$ stage 3-5; with complications others, was higher than of the one without the above characteristics, $p<0.05$. Conclusion: Increased $A U$ is common in patients with type 2 diabetic mellitus with chronic nephropathy.

Keywords: Type 2 diabetic mellitus, chronic nephropathy, acid uric.

\section{I. ĐĂT VẤN ĐỀ}

Đái tháo đường típ 2 ngày càng gia tăng trên thế giới và trẻ hoá, với cơ chế bệnh sinh liên quan đến kháng insulin và giảm chức năng tế bào beta [1],[2]. Ở bệnh nhân đái tháo đường típ 2 cần kiểm soát nhiều yếu tố gồm glucose máu, rối loạn lipid máu, huyết áp... Những bênh nhân kiểm soát kém các yếu tố, thường xuất hiện các biến chứng sớm, trong đó có biến chứng thân. Biểu hiện tổn thương thân ở bênh nhân đái tháo đường típ 2 sớm nhất là sự xuất hiện albumin niệu, cụ thể là microalbumin niệu. Trên lâm sàng biến chứng thận có thể gặp dạng protein niêu có hoặc không hội chứng thận hư, và hoặc kèm theo suy thâan man tính [3]. Acid uric máu ngày càng được nghiên cứu nhiều và được xem như một yếu tố tiên lượng độc lập nguy cơ tim mach cũng như tỷ lệ sống còn ở các bệnh nhân mắc bênh mạn tính. Nhiều nghiên cứu trên thế giới đã khẳng định: tăng nồng độ acid uric huyết thanh ở bệnh nhân đái tháo đường nói chung, bệnh nhân đái tháo đường có tổn thương thân nói riêng chính là một yếu tố nguy cơ độc lập quan trọng và có giá trị trong chẩn đoán, tiển lượng bệnh nhân [4],[5],[6]. Xuất phát từ những lý do trên, chúng tôi thực hiện đề tài này với mục tiêu: Khảo sát nồng độ 
acid uric huyêt tương ở bệnh nhân đái tháo đường típ 2 có bệnh thận mạn tính.

\section{II. ĐỐI TƯỢNG VÀ PHƯƠNG PHÁP NGHIÊN CỨU}

1. Đối tượng nghiên cứu. Đối tượng là156 người bệnh được chia làm 2 nhóm:

- Nhóm nghiên cứu (Nhóm 1): Là 98 người bệnh ĐTÐ típ 2 có BTMT.

- Nhóm chứng bệnh (Nhóm 2): Là 58 người bênh ĐTĐ típ 2 không có BTMT.

- Thời gian nghiên cứu từ tháng 4/2020 đến tháng 4/2021.

- Nơi nghiên cứu: Bệnh viện nhân dân 115.

Tiêu chuẩn chọn bệnh nhân:

- Bệnh nhân được chẩn đoán ĐTĐ típ 2 đang được theo dõi và điều trị tại Bệnh viện.

- Gồm 2 nhóm có và không có BTMT (BTMT được xác định sau ĐTĐ típ 2).

- Bệnh nhân đồng ý tham gia nghiên cứu

Tiêu chuẩn loại bệnh nhân:

- Bênh nhân tại thời điểm nghiên cứu nghi ngờ mắc bệnh ngoại khoa.

- Bệnh nhân viêm nhiễm nặng như viêm phổi, viêm tuy. cấp...

- Các bệnh nhân không đủ tiêu chuẩn nghiên cứu.

\section{Phương pháp nghiên cứu}

- Nghiên cứu mô tả, cắt ngang so sánh bệnh và chứng bênh.

- Tính cỡ mẫu theo công thức: Chọn mẫu thuận tiện trong thời gian nghiên cứu.

- Bênh nhân được hỏi bênh sử, khám lâm sàng. Các xét nghiệm cận lầm sàng bao gồm: xét nghiệm công thức máu, sinh hoá máu các chỉ số: glucose, ure, creatinine, albumin, protein..., nước tiểu 10 chỉ tiêu, siêu âm thận, protein niêu 24 giờ nếu cần. Tính mức lọc cầu thận theo công thức MDRD.

- Bệnh nhân có $M L C T<60 \mathrm{ml} /$ phút và hoặc protein niêuu $(+)$ trong 3 tháng liên tuc được xểp nhóm 1, những bênh nhân có $M L C T \geq 60 \mathrm{ml} /$ phút và protein niệu (-) được xếp nhóm 2.

- Định lượng acid uric (AU) huyết tương theo nguyên lý enzyme. Chẩn đoán tăng $\mathrm{AU}$ máu ở nam > 420 $\mu \mathrm{mol} / \mathrm{L}$, nữ $>369 \mu \mathrm{mol} / \mathrm{L}$.

3. Xử lý số liệu:Số liệu được xử lý bằng thuật toán thống kê y sinh học theo chương trình SPSS 20.0

\section{KẾT QUẢ NGHIÊN CỨU}

Tuổi trung bình nhóm bệnh nhân ĐTÐ típ 2 có BTMT là $69,87 \pm 14,18$, tỷ lệ nam là $41,8 \%$, nữ chiếm $58,2 \%$. Mức lọc cầu thận trung bình là $52,46(44,66$ - 58,96)ml/phút, trong đó có 77,5\% bệnh nhân có BTMT giai đoạn 3 đến 5 .

Bảng 1. So sánh giá trị acid uric của đôi tượng nghiên cứu

\begin{tabular}{|c|c|c|c|c|c|}
\hline \multicolumn{2}{|c|}{ Đặc điếm } & Chung (n=156) & Nhóm 1 (n=98) & Nhóm2 (n=58) & p \\
\hline \multirow{4}{*}{ AU ( $\mu$ mol/l) $)$} & $\begin{array}{c}\text { Trung vị } \\
\text { (IQR) }\end{array}$ & 393,9 & 423,55 & 341,15 & $<0,001$ \\
\cline { 2 - 6 } & Min & $(316,85-491,62)$ & $(333,6-524,35)$ & $(297,2-408,95)$ & - \\
\cline { 2 - 6 } & Max & 152,4 & 152,4 & 195,6 & - \\
\hline \multicolumn{2}{|c|}{ Tỷ lệ tăng $(\%)$} & 482,4 & 852,4 & 632 & $<0,001$ \\
\hline
\end{tabular}

Nhóm bệnh nhân ĐTĐ có BTMT có nồng độ trung bình $\mathrm{AU}$ và tỷ lệ tăng cao hơn nhóm không có BTMT, $\mathrm{p}<0,001$.

Bảng 2. Liên quan nồng độ AU huyết tương với tuổi cao và giới ( $n=98$ )

\begin{tabular}{|c|c|c|c|}
\hline \multicolumn{2}{|c|}{ Đặc điếm } & Số bệnh nhân & Tỷ lệ (\%) \\
\hline \multirow{2}{*}{ Nũ $(n=57)$} & Tăng & 39 & 68,4 \\
\hline & Trung vị (Tứ phân vị) & \multicolumn{2}{|c|}{$426,1(339,2-522,7)$} \\
\hline \multirow{2}{*}{$\operatorname{Nam}(n=41)$} & Tăng & 20 & 48,8 \\
\hline & Trung vị (Tứ phân vị) & \multicolumn{2}{|c|}{$416,6(328,5-531,95)$} \\
\hline \multicolumn{2}{|r|}{$\mathrm{p}$} & \multicolumn{2}{|c|}{$>0,05$} \\
\hline \multirow{2}{*}{$\geq 60$ tuổi $(n=77)$} & Tăng & 51 & 66,2 \\
\hline & Trung vị (Tứ phân vị) & \multicolumn{2}{|c|}{$439,3(355,4-523,45)$} \\
\hline \multirow{2}{*}{$<60$ tuổi $(n=21)$} & Tăng & 8 & 38,1 \\
\hline & Trung vị (Tứ phân vị) & \multicolumn{2}{|c|}{$353(293,2-541,95)$} \\
\hline & tỷ lệ & & \\
\hline
\end{tabular}

Không có mối liên quan nồng độ $A U$ huyết tương với giới $p>0,05$, tuy nhiên nhóm BN tuổi từ 60 trở lên có tỷ lệ tăng AU cao hơn nhóm < 60 tuổi, $p<0,05$.

Bảng 3. Liên quan với rối loạn lipid máu và tình trạng kiểm soát glucose máu

\begin{tabular}{|c|c|c|c|}
\hline \multicolumn{2}{|c|}{ Đặc điếm } & Số bệnh nhân & Tỷ lệ (\%) \\
\hline \multirow{2}{*}{$\begin{array}{c}\text { Có RLLP máu } \\
(n=57)\end{array}$} & Tăng & 43 & 64,2 \\
\cline { 2 - 4 } & Trung vị (Tứ phân vị) & $444,2(343,4-543,2)$ \\
\hline
\end{tabular}


TẠP CHÍ Y HỌC VIỆT NAM TẬP 503 - THÁNG 6 - SỐ 2 - 2021

\begin{tabular}{|c|c|c|c|}
\hline \multirow{2}{*}{ Không (n=41) } & Tăng & 16 & 51,6 \\
\hline & Trung vị (Tứ phân vị) & \multicolumn{2}{|c|}{$400(299,2-465,9)$} \\
\hline \multicolumn{2}{|r|}{$\mathrm{OR}, \mathrm{p}$} & \multicolumn{2}{|c|}{$\mathrm{OR}=1,68, p>0,05$} \\
\hline \multirow{2}{*}{$\begin{array}{c}\text { Kiểm soát kém } \\
(n=70)\end{array}$} & Tăng & 39 & 55,7 \\
\hline & Trung vị (Tứ phân vị) & \multicolumn{2}{|c|}{$409,25(328,27-526,25)$} \\
\hline \multirow{2}{*}{$\begin{array}{l}\text { Tốt+Chấp nhâan } \\
\text { được }(n=28)\end{array}$} & Tăng & 20 & 71,4 \\
\hline & Trung vị (Tứ phân vị) & \multicolumn{2}{|c|}{$443,15(351,75-525,27)$} \\
\hline \multicolumn{2}{|c|}{$\mathrm{OR}, \mathrm{p}$} & \multicolumn{2}{|c|}{$\mathrm{OR}=0,503, p>0,05$} \\
\hline
\end{tabular}

Nhận xét: Không có mối liên quan giữa AU với RLLP máu và mức độ kiếm soát glucose máu lúc đói, $p>0,05$.

Bảng 4. Liên quan với giai đoạn bệnh thận và biến chứng ngoài thận

\begin{tabular}{|c|c|c|c|}
\hline \multicolumn{2}{|c|}{ Đăc điểm } & Số bệnh nhần & Tỷ lệ (\%) \\
\hline \multirow{2}{*}{$\begin{array}{l}\text { Giai đoạn 3-5 } \\
\quad(n=75)\end{array}$} & Tăng & 53 & 70,7 \\
\hline & Trung vị (Tứ phân vị) & \multicolumn{2}{|c|}{$462,1(367-543,8)$} \\
\hline \multirow{2}{*}{$\begin{array}{c}\text { Giai đoạn } 1-2 \\
(n=\dot{2} 3)\end{array}$} & Tăng & 6 & 26,1 \\
\hline & Trung vị (Tứ phân vị) & \multicolumn{2}{|c|}{$316,6(271-426,1)$} \\
\hline \multicolumn{2}{|r|}{$\mathrm{OR}, \mathrm{p}$} & \multicolumn{2}{|c|}{$\mathrm{OR}=6,826, \mathrm{p}<0,001$} \\
\hline \multirow{2}{*}{$\begin{array}{l}\text { Có biến chứng } \\
\text { khác }(n=82)\end{array}$} & Tăng & 54 & 65,9 \\
\hline & Trung vị (Tứ phân vị) & \multicolumn{2}{|c|}{$447,1(353,6-536,22)$} \\
\hline \multirow{3}{*}{ Không có $(n=16)$} & Tăng & 5 & 31,3 \\
\hline & Trung vị (Tứ phân vị) & \multirow{2}{*}{\multicolumn{2}{|c|}{$332,05(266,87-417,55)$}} \\
\hline & $R, p$ & & \\
\hline
\end{tabular}

Nhận xét: Có mối liên quan nồng độ $A U$ với giai đoạn bệnh thận mạn tính, và biến chứng ngoài thận có ý nghĩa, $\mathrm{p}<0,05$.

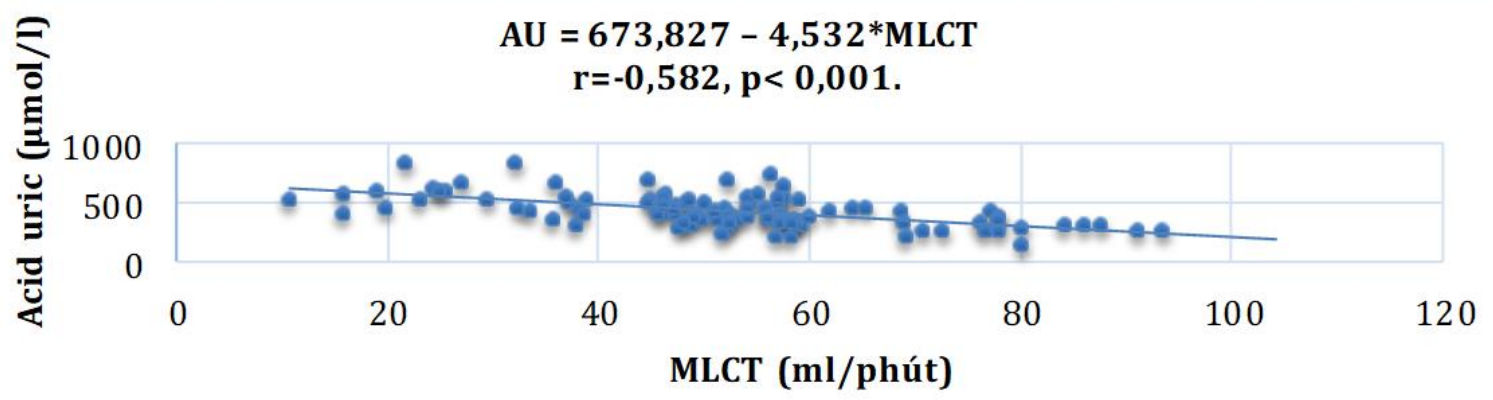

Biểu đồ 1. Tương quan giữa nồng độ acid uric máu và mức lọc cầu thận nhóm bệnh $(n=98)$

Nhận xét: Có mối tương quan nghịch giữa AU và MLCT với hệ số tương quan $r=-0,582, p<0,001$.

\section{BÀN LUÂN}

1. Đặc điểm nồng độ AU: Kết quả nghiên cứu của chúng tôi cho thấy, có tới $60,2 \%$ bệnh nhân ĐTĐ típ 2 có tổn thương thận có tăng AU máu, cao hơn nhóm ĐTĐ típ 2 chưa có tổn thương thận là 29,3\%, p< 0,001. Tăng AU tương đối phổ biến ở bệnh nhân ĐTĐ có bệnh thận mạn.

Bảng 5. So sánh đặc điểm AU máu với các nghiên cứu trong và ngoài nước

\begin{tabular}{|c|c|c|c|}
\hline Tác giả & Đối tượng & Tỷ lệ tăng & $\begin{array}{c}\text { Nồng độ trung bình } \\
(\mu \mathrm{mol} / \mathrm{L})\end{array}$ \\
\hline $\begin{array}{c}\text { Yan D. và cộng sự } \\
\text { năm } 2015 \text { [7] }\end{array}$ & - 3212 BN ĐTĐ típ 2 & $18,7 \%$ & - \\
\hline $\begin{array}{l}\text { Lê Xuân Trường và } \\
\text { cộng sự năm } 2016 \text { [8] }\end{array}$ & - 197 bệnh nhân ĐTĐ típ 2 & $38,1 \%$ & $\begin{array}{c}\text { Nam: 476,32 } \pm 45,07 \\
\text { Nữ: } 436,67 \pm 33,89\end{array}$ \\
\hline Chúng tôi 2021 & $\begin{array}{c}156 \text { bệnh nhân ĐTĐ típ 2: } \\
\text { - } 98 \text { BN ĐTĐ típ } 2 \text { có BTMT: nam } \\
41,8 \% \text { và nữ 58,2\%. } \\
\text { - } 58 \text { BN ĐTĐ típ } 2 \text { không có BTMT: } \\
\text { nam } 44,8 \% \text { và nữ } 55,2 \% \text {. }\end{array}$ & $\begin{array}{l}48,7 \% \\
60,2 \% \\
29,3 \%\end{array}$ & $\begin{array}{l}393,9 \\
423,55 \\
341,15\end{array}$ \\
\hline
\end{tabular}


Tăng axit uric huyết thanh cũng là một trong những yếu tố dự báo độc lập tốt nhất của bệnh ĐTÐ và thường báo trước sự phát triển của cả đề kháng insulin và bệnh ĐTĐ [5],[6]. Axit uric tăng cao cũng dự đoán độc lập sự phát triển của gan nhiễm mõ̃, béo phì, tăng huyết áp và tăng protein phản ứng $\mathrm{C}$. Hơn nữa, hội chứng chuyển hóa có liên quan đến tần suất tăng axit uric máu cao, và ngược lại, tăng axit uric máu có liên quan đến hội chứng chuyển hóa. Mặc dù tăng insulin máu có thể góp phần làm tăng axit uric máu bằng cách ngăn chặn bài tiết axit uric, nhưng nó không thể là lý do chính dẫn đến mối liên hệ này vì tăng axit uric máu đãđược báo cáo là có trước sự phát triển của tăng insulin máu và/hoặc bệnh ĐTĐ. Như vậy, tăng AU và bệnh ĐTÐ có mối quan hệ 2 chiều, lý giải tại sao ở bệnh nhân ĐTÐ lại có một tỷ lệ tăng AU. Với bểnh nhân ĐTÐ có tổn thương thận, đặc biệt giảm MLCT mạn tính, tăng $A U$ còn là hậu quả của giảm MLCT, thận không lọc được AU nên nồng độ $A U$ lại càng tăng cao. Kết quả nghiên cứu của chúng tôi cũng như các tác giả khác cho thấy sự phù hợp: ở nhóm bệnh nhân ĐTĐ có BTMT nồng độ $A U$ và tỷ lệ tăng $A U$ cao hơn nhóm ĐTÐ chưa có tổn thương thần.

2. Liên quan nồng độ AU với một số đặc điểm bệnh nhân: Nghiển cứu của chúng tôi cho thấy bệnh nhân ĐTĐ típ 2, tỷ lệ tăng nồng độ $\mathrm{AU}$ ở nhóm cao tuổi cao hơn nhóm bênh nhân thấp tuổi có ý nghĩa, $\mathrm{p}<0,05$. Mặc dù tắng $A U$ và bệnh gút chủ yếu gặp ở nam giới, tuy nhiên với bệnh nhân ĐTÐ có BTMT thì không có mối liên quan đến giới điều này cho thấy, tăng $\mathrm{AU}$ chủ yếu liên quan đến cơ chế bệnh sinh do giảm MLCT mà thôi. Với người cao tuổi, chức năng thận giảm hơn người trẻ tuổi, và tuổi cao cũng là yếu tố nguy cơ gây tăng $A U$ máu nên kết quả nghiên cứu của chúng tôi chấp nhận được.Chúng tôi nhận thây rằng nhóm bệnh nhẩn kiểm soát glucose máu kém có nồng độ $A U$ có xu hướng thấp hơn, mặc dù chưa có ý nghĩa thống kê (nồng độ 409,25 $\mu \mathrm{mol} / \mathrm{L}$ so với 443,15 $\mu \mathrm{mol} / \mathrm{L}$ ). Thật vậy, nồng độ axit uric huyết thanh có xu hướng thấp ở những đối tượng kiểm soát đường huyết kém. Vì kiểm soát tốt bệnh tiểu đường có liên quan chặt chẽ với việc tái bảo vệ, nên người ta có thể dự đoán rằng nồng độ axit uric tăng cao sẽ liên quan đến kết quả thận tốt hơn [7],[8]. Kết quả nghiên cứu của chúng tôi cho thấy có mối liên quan giữa nồng độ $\mathrm{AU}$ với giai đoạn bệnh thận, nhóm bệnh nhân giai đoạn 3,4 và 5 có nồng độ $A U$ cao hơn nhóm bệnh nhân BTMT giai đoạn 1 và $2, p<0,05$. Nồng độ
AU máu có mối tương quan nghịch với MLCT, $r=-582, p<0,001$. Việc nghiên cứu vai trò của axit uric trong $\mathrm{BTMT}$ là rất khó khăn vì axit uric được bài tiết chủ yếu qua thận, và do đó giảm mức lọc cầu thận chắc chắn đi kèm với tăng nồng độ axit uric trong huyết thanh (như kết quả nghiên cứu của chúng tôi). Điều này gây khó khăn cho việc đánh giá vai trò của acid uric trong sự tiến triển của bệnh thận ở những bệnh nhân mắc bệnh thận mạn tính. Biến chứng ngoài thân thường đi kèm với tình trang kiểm soát glucose máu kém. Kết quả nghiên cứu của chúng tôi cho thấy, những bệnh nhân có thêm các biến chứng khác ngoài thận có nồng độ trung bình và tỳ lệ tăng nồng độ $\mathrm{AU}$ cao hơn nhóm chỉ có biến chứng thận. Những kết quả này một lần nữa cho thấy mổi liên quan giữa $A U$ và các biến chứng khác ngoài thận ở bệnh nhân ĐTÐ típ 2.

\section{KẾT LUÂ̂N}

- Nồng độ AU huyết tương trung bình ở nhóm ĐTÐ có BTMT là 423,55(333,6 - 524,35) $\mu \mathrm{mol} / \mathrm{L}$, cao hơn nhóm không có BTMT là 341,15 (297,2 $408,95) \mu \mathrm{mol} / \mathrm{L}, \mathrm{p}<0,001$. Tỷ lệ bệnh nhân ĐTĐ có BTMT tăng AU là $60,2 \%$ cao hơn nhóm không có BTMT là $29,3 \%, p<0,001$.

- Nhóm bệnh nhân ĐTĐ có BTMT tuổi từ 60 trở lên; bệnh thận mạn giai đoạn 3-5; có biến chứng khác ngoài thận có nồng độ $A U$ cao hơn nhóm không có đặc điểm trên, $\mathrm{p}<0,05$.

\section{TÀI LIỆU THAM KHẢO}

1. Yang L, Shao J, Bian Y, et al. (2016). Prevalence of type 2 diabetes mellitus among inland residents in China (2000-2014): A metaanalysis.J Diabetes Investig. 7(6):845-852.

2. Xu G, Liu B, Sun Y, et al. (2018). Prevalence of diagnosed type 1 and type 2 diabetes among US adults in 2016 and 2017: population based study.BMJ. 2018 Sep 4;362:k1497.

3. Lê Việt Thắng (2019). Bệnh thận do đái tháo đường. Cập nhất chẩn đoán, điêuu trị một số bệnh nôi tiểt và̀ chuyển hoá hay gắp. Trang: 123-129.

4. Mauer M, Doria A. (2018). Uric Acid and Diabetic Nephropathy Risk. Contrib Nephrol. 192:103-109.

5. Razi $F$, Nasli-Esfahani $E$, Bandarian $F$. (2018). Association of serum uric acid with nephropathy in Iranian type 2 diabetic patients.] Diabetes Metab Disord. 17(1):71-75.

6. Singh K, Kumar P, Joshi A, et al. (2019).Study of association of serum uric acid with albuminuria and carotid atherosclerosis in type 2 diabetes mellitus patients.J Family Med Prim Care. 8(12): 4027-4031.

7. Yan D, Tu Y, Jiang F, et al. (2015). Uric Acid is independently associated with diabetic kidney disease: a cross-sectional study in a Chinese population.PLoS One. 10(6):e0129797. 